\title{
Living on the Edge: Changes in the Foraging Strategy of a Territorial Ant Species Occurring with a Rival Supercolony - a Case Study
}

\author{
István Maák • Zsolt Czekes • Katalin Erős • \\ Zsófia Pálfi • Bálint Markó
}

Received: 16 July 2019/Revised: 11 May 2020 / Accepted: 20 May 2020 /Published online: 10 June 2020

(C) The Author(s) 2020

\begin{abstract}
Territorial strategy in animals is characterized by the monopoly of resources inside a protected area, the territory. The presence of territorial species considerably alters the behavior of co-occurring submissives, as it is known in several submissive ant species living on the territories of red wood ants in temperate regions. On the other hand, as a rule, territorial species cannot share the same territory and usually exclude each other. However, this 'rule' is inferred from the almost complete lack of data on the coexistence of rival territorials, and not from observations regarding the effective exclusion or
\end{abstract}

Electronic supplementary material The online version of this article (https://doi.org/10.1007/s10905-020-09745-x) contains supplementary material, which is available to authorized users.

I. Maák $(\bowtie)$

Laboratory of Social and Myrmecophilous Insects, Museum and Institute of Zoology, ul. Wilcza 64, Warsaw 00-679, Poland e-mail:bikmakk@gmail.com

Z. Czekes · K. Erős · B. Markó

Hungarian Department of Biology and Ecology, Babeş-Bolyai University, Clinicilor 5-7, Cluj-Napoca 400006, Romania

B. Markó

e-mail: marko.balint@ubbcluj.ro

\section{Z. Pálfi}

School of Environmental Sciences, Charles Stuart University, PO Box 789, Albury, NSW 2640, Australia

\section{B. Markó}

Department of Ecology, University of Szeged, Közép fasor 52, Szeged 6726, Hungary behavioral inhibition of one territorial species by other. In the frame of this study, we investigated the foraging strategy of the territorial red wood ant Formica pratensis that occurred inside a large polydomous system of another territorial ant species, F. exsecta. Formica pratensis colonies outside the supercolony served as control. Within the $F$. exsecta supercolony, $F$. pratensis showed the characteristics of a subordinate species characterized by low discovery and exploitation success of artificial food sources. On the contrary, control colonies outside the polydomous system clearly behaved like typical territorials as they successfully monopolized the majority of the baits. In addition, submissive species were more successful around the $F$. pratensis nests within the supercolony, than outside of it. As suggested by our results, territorial species could co-occur with other territorials given certain plasticity in their behavior and small colony size. Nevertheless, exclusion also happens as proven by our field observations.

Keywords Competition - Formica cunicularia . Interspecific relationships · Myrmica spp. Polydomy . Submissive species

\section{Introduction}

Competition occurs when the ecological requirements of species overlap (Pianka 1974; Glen and Dickman 2008). The negative effects of competitive interactions can be reduced if the morphological, behavioral, and ecological plasticity of the competing partners allow 
shifts in their requirements, thus minimizing niche overlap as has been observed also in ants (see Cerdá et al. 2013 for a review). Territoriality is the most effective strategy to ensure the control of resources in ants (Hölldobler and Wilson 1990; Adams 2016). Territorial ant species usually dominate their foraging grounds, wherein they exert competitive pressure on the cohabiting ant species (Savolainen and Vepsäläinen 1988, 1989; Pisarski and Vepsäläinen 1989; Petráková and Schlaghamerský 2011; Czechowski et al. 2013; Adams 2016; Trigos-Peral et al. 2016; Ślipiński et al. 2018).

In temperate regions, the composition of an ant assemblage is mostly determined by intra- and interspecific competition for food and suitable nesting places (Savolainen and Vepsäläinen 1988; Braschler and Baur 2003). Clear division of food resources contributes to the decrease in competitive pressure (Levings and Traniello 1981; Sorvari and Hakkareinen 2004) and can be related to morphological and behavioral differences (Davidson 1977; Gordon 2010). The cohabitation of two morphologically similar species can be mediated by behavioral differences. For instance, if a species can dominate in the contest competition due to its aggressive behavior, the other will adjust its foraging strategy by being faster in retrieving the prey and/or more efficient in discovering food supplies (Reznikova 1981; Savolainen 1991; Gordon 2010). However, other factors can also play an important role in determining species co-occurrence (Vepsäläinen and Pisarski 1982; Savolainen and Vepsäläinen 1989; Czechowski et al. 2013; Adams 2016; Stuble et al. 2017).

Territoriality in ants sometimes involves the development of multi-nest polydomous systems, consisting of interrelated nests formed by nest fissions, so-called 'budding', with intense worker and information exchange. The extreme form of such systems, where several hundred or thousands of nests form the cooperative network is called supercolony (Debout et al. 2007; Erös et al. 2009; Csata et al. 2012; Ellis and Robinson 2014; Adams 2016; Schultner et al. 2016; Wiezik et al. 2017). Such polydomous species efficiently exploit the available food supplies (Debout et al. 2007; Erős et al. 2009; Csata et al. 2012), and because of high worker density, they have a strong negative effect on other ant species (e.g. Czechowski et al. 2013, Trigos-Peral et al. 2016). Under normal circumstances, a lower-ranked species can cohabit with a species of a higher level, but when resources diminish, the competition between them increases to an extent that could end coexistence
(Savolainen and Vepsäläinen 1988; Markó and Czechowski 2004; Cerdá et al. 2013; Czechowski et al. 2013; Markó et al. 2013; Ślipiński et al. 2014). On the other hand, as a rule, in the temperate region, territorial species exclude each other. However, there is a lack of empirical evidence concerning territory sharing of top dominant ant species. Such conditions, when two different territorial species share to some extent space and persist for a given period together, are rarely or not even observed in nature (see e.g. Petráková and Schlaghamerský 2011; Czechowski et al. 2013). Discovery of two colonies of the territorial ant Formica pratensis inside a large $F$. exsecta polydomous system tightly surrounded by nests of the rival, created the possibility for a unique case study. The questions related to their ways of co-existence immediately came up: (a) do they share the same territory? (b) do the two territorial species exert different impacts on other co-occurring ant species? and finally, (c) can we observe changes in the foraging strategy of $F$. pratensis that would ensure its coexistence with the supercolonial species at least for a certain period of time?

\section{Materials and Methods}

Species and Site

Both Formica (Formica) pratensis Retzius, 1783 and Formica (Coptoformica) exsecta Nylander, 1846 are relatively common, Pan-Palearctic, mound-building, territorial ant species. Formica pratensis usually occurs in open areas, on grasslands from the plain areas to mountain pastures, up to $1500 \mathrm{~m}$ in the Alps (Seifert 2007). Generally, it forms monodomous and monogynous colonies, but polydomous systems are also known. Nests are usually large, they can reach a diameter of $300 \mathrm{~cm}$ (Seifert 2007), containing tens of thousands of workers (Czechowski et al. 2012). It keeps a large territory around its nests with a diameter of several tens of meters and maintains trunk trails leading to aphid colonies, which can persist even for 15 years (Seifert 2007). With the help of these trunk trails and by a large number of foragers, $F$. pratensis very efficiently covers its territory.

F. exsecta inhabits open areas in mixed and deciduous forests, mostly forest edges, forest clearings or mountain pastures (Seifert 2000). Large polydomous colonies are known from the Alps, Central Europe, 
and European Russia which consist of several hundreds of nests (see Markó et al. 2012 for a review; Wiezik et al. 2017). Usually, nests of $F$. exsecta are smaller than those of $F$. pratensis. Nest mound diameter ranges from $10 \mathrm{~cm}$ in incipient to above $1 \mathrm{~m}$ in mature nests (Seifert 2000; Erős et al. 2009; Csata et al. 2012; Wiezik et al. 2017), and nests contain several hundred to several hundred thousand individuals (Sorvari 2009; Wiezik et al. 2017). Territories of monodomous colonies are also smaller, than those of $F$. pratensis, covering from a few square meters to $60 \mathrm{~m}^{2}$ (Pisarski 1982; Sorvari 2009; Erős et al. 2009; Csata et al. 2012).

The investigations were carried out in Central Romania, in the southern part of the Giurgeului Depression in the Eastern Carpathians in July 2009. The depression is one of the coldest regions in Romania; frosts are still common in May and can occur as early as September. There are nine large polydomous systems of $F$. exsecta in the southern part of the depression, in addition to several monodomous colonies (Markó et al. 2012). The largest polydomous system selected for the purpose of our study $\left(46^{\circ} 36^{\prime} \mathrm{N}, 25^{\circ} 36^{\prime} \mathrm{E}, 780 \mathrm{~m}\right.$ a.s.1.), is a genuine supercolony comprised of more than 3,400 nests stretching over more than 20 ha (Markó et al. 2012). This polydomous system is located in a fen meadow with Molinia caerulea, Deschampsia caespitosa, Festuca pratensis, Briza media, Nardus stricta, Succisa pratensis, Stachys officinalis, and Cirsium palustre as the most abundant or characteristic plant species. The area is overgrown with scattered small trees and saplings of Betula pubescens, Picea abies, Frangula alnus, and Salix spp. The meadow is fairly intensely grazed by cows for most of the year. The structure of the $F$. exsecta polydomous systems as well as intraspecific and mutualistic relationships of $F$. exsecta to other species are well studied (Goropashnaya et al. 2007; Erős et al. 2009; Martin et al. 2009; Csata et al. 2012; Markó et al. 2012; Trigos-Peral et al. 2016).

Altogether four $F$. pratensis nests were used in the study, two of which were located inside the large $F$. exsecta polydomous system (further on I-1 and I-2; Fig. S1) and the other two nests were outside the polydomous system, but still close to its border (further on O-1 and O-2; Figs. S2-3). The latter two nests served as controls, as it could be assumed that here the effect of $F$. exsecta would be weak, if any. The distance between nests I-1 and I-2 was $10.05 \mathrm{~m}$ and they were closely surrounded by $24 F$. exsecta nests (see Fig. S1). Since there were no observed visible trails connecting them, we assumed that they were separate colonies. The average distance between nest I-1 and the $F$. exsecta nests surrounding it was $12.4 \mathrm{~m}(\mathrm{SD} \pm 3.39, \min 8.05 \mathrm{~m})$, and $9.04 \mathrm{~m}$ for $\mathrm{I}-2(\mathrm{SD} \pm 3.35$, min $8.05 \mathrm{~m})$. Both colonies tended eight separate aphid colonies at a mean distance of $2.95 \mathrm{~m}(\mathrm{SD} \pm 1.43$, $\min 0.4 \mathrm{~m}, \max 4.6 \mathrm{~m})$ and 2.64 $\mathrm{m}(\mathrm{SD} \pm 1.24$, min $0.4 \mathrm{~m}, \max 3.8 \mathrm{~m})$, respectively.

The distance between nests O-1 and O-2 was $>100$ $\mathrm{m}$. No trails were detected between them or other $F$. pratensis nests, thus they could be also treated as monodomous colonies. A single $F$. exsecta nest was in the vicinity of O-1 located at $10.75 \mathrm{~m}$. In addition, there were three $F$. (Raptiformica) sanguinea Latr. nests around $\mathrm{O}-1$ with a mean distance of $8.03 \mathrm{~m}(\mathrm{SD} \pm 1.9$, min $10.75 \mathrm{~m}$; see Fig. S2). This facultative slave-maker species is known to apply a strange dominant strategy. It is, generally, weaker than $F$. pratensis or $F$. exsecta (see Trigos-Peral et al. 2016). In O-2, there were two $F$. exsecta nests at 10.9 and $18.31 \mathrm{~m}$, and three nests of the submissive $F$. (Serviformica) cunicularia species with a mean distance of $10.83 \mathrm{~m}(\mathrm{SD} \pm 3.34$, min 10.9 m) (see Fig. S3). O-1 tended 48 aphid colonies with a recorded average distance of $12.19 \mathrm{~m}(\mathrm{SD} \pm 8, \min 0.8$ $\mathrm{m}$, max $30 \mathrm{~m}$ ), whereas $\mathrm{O}-2$ exploited 23 aphid colonies with an average distance of $6.42 \mathrm{~m}(\mathrm{SD} \pm 4.1, \min 0.6$ $\mathrm{m}, \max 14.1 \mathrm{~m})$.

\section{Study Methods}

Transects of observation plots $(20 \times 20 \mathrm{~cm}$ quadrats $)$ were set up to determine under undisturbed conditions the distribution and abundance of ant species. The 1st transect inside the supercolony connected the two focal $F$. pratensis nests (both being surrounded by more $F$. exsecta nests), whereas outside the supercolony each focal $F$. pratensis nest with the nearest $F$. exsecta nest. The transects also extended in the other direction from the nests along the same axis, whereas the 2nd transect was placed perpendicular to the axis of 1 st transect (see Fig. S1-3). The setup allowed us to trace the transition between the territories of the two focal species. There was $1 \mathrm{~m}$ between the centers of two consecutive observation plots. At nests I-1 and I-2, the 1 st transect consisted of 17 plots with 9 plots being established between the two colonies, whereas the 2 nd transects contained 16 plots (altogether 28 and 29 obs. plots, respectively; see also Fig. S1). At nests O-1 and O-2, the $1 \mathrm{st}$ transects consisted of 17 plots and connected the focal nests with the nearest $F$. exsecta colonies that were 
located at 10.75 and $10.9 \mathrm{~m}$, respectively, whereas the 2nd transects consisted of 16 plots (altogether 33 and 33 obs. plots, respectively; see Fig. S2-3).

Baits are widely accepted means of studying ant foraging behavior around their nests. However, the presence of large food sources enhance and thus alter the activity of ants in the specific area in which a bait is placed (e.g. Vepsäläinen and Pisarski 1982; Savolainen and Vepsäläinen 1988; Vepsäläinen and Savolainen 1990; Sanders and Gordon 2003; Markó and Czechowski 2004; Petráková and Schlaghamerský 2011; Markó and Czechowski 2012; Czechowski et al. 2013; Ślipiński et al. 2018). For this reason, we recorded the distribution of foragers in the absence (further on 'nudum' observations) and in the presence of baits as well, in order to obtain an appropriate view of the foraging strategy of a specific ant species (see also Markó and Czechowski 2004; Czechowski and Markó 2005; Markó and Czechowski 2012; Czechowski et al. 2013; Ślipiński et al. 2018). Interspecific conflicts were also recorded. Observations were carried out on sunny days with fair weather conditions for two periods in a day involving the activity peak of the ant species in this habitat: between $9 \mathrm{AM}$ and $12 \mathrm{AM}$, and between $4 \mathrm{PM}$ and 7 PM. During mid-day, due to elevated temperatures, the activity of the species dropped significantly with only a few observed active workers on the trunk trails. Within each period, each plot was checked for one $\mathrm{min}$ at $20 \mathrm{~min}$ intervals, which yielded a total of 18 observations per plot per day. First-day observations were carried out in the absence of baits (nudum), which were followed by bait observations next day. To avoid effects due to seasonal variation in food preferences, baits contained both animal protein (tuna flakes) and carbohydrate (mixed-flower honey) (Markó and Czechowski 2004, 2012; Czechowski and Markó 2005; Petráková and Schlaghamerský 2011; Czechowski et al. 2013; Ślipiński et al. 2018). Bait portions of ca. $3.5 \mathrm{~cm}$ in diameter were placed on $10 \mathrm{~cm}$ diameter green plastic plates in the center of each plot. The plates and portions were set-up $10 \mathrm{~min}$ before the first observation at the beginning of each observation period, retrieved at the end of each period and then rinsed with water.

\section{Statistical Analysis}

The distribution of most frequent species around the focal $F$. pratensis nest in nudum observations (both inside and outside the polydomous system) were analyzed using Generalized Linear Mixed Model approach (GLMM, Poisson error, maximum likelihood) with colonial identity as the input factor, while observation time and the identity of the observation plots were included as random factors.

The interaction between the four most abundant species (two focal species and two subordinates - Myrmica spp. and F. cunicularia) and the effect of distance from the focal $F$. pratensis colony (further on distance) were analyzed also using GLMM approach (Poisson error, maximum likelihood) separately for nudum and bait observations. Distance from the focal nests and abundance of rival foragers were included as covariates, while observation time, colonial identity and the identity of the observation plots as random factors. Data for each observation period was used separately $\left(\mathrm{N}_{\text {inside supercolony }}\right.$ $\left.=1026 ; \mathrm{N}_{\text {outside supercolony }}=1188\right)$. To test the predictability of the baits' exploitation pattern - inferred from the abundance of ants at baits -, we also included the abundance of the respective species recorded during nudum observations as a covariate in the models testing their occurrence at baits.

The normality of datasets was regularly tested with Kolmogorov-Smirnov test but none proved to be of normal distribution. In model over-dispersion, negative binomial error term was applied. In every model, automated model selection was carried out, and the effects of different explanatory factors and variables were averaged across the best models with delta $<2$ (see Grueber et al. 2011). Since $F$. exsecta individuals were not recorded at baits outside the polydomous system, the number of $F$. exsecta individuals were not included in these GLMM analyses. The tables containing the GLMM models included in the average best-models are stored as digital supplementary material to this article (Tables S1-4).

All statistical analyses were carried out in an R Statistical Environment (R Core Team 2018). GLMMs were performed using the glmer function in the lme 4 package (Bates et al. 2013), automated model selection with the help of the dredge function in the MuMIn package (Barton 2013). The lsmeans function from lsmeans package was used in order to carry out posthoc sequential comparisons among factor levels when performing GLMM analyses (Russell 2016) and used the Tukey method (p.adjust function) to correct the $p$ values for multiple comparisons. 


\section{Results}

Species Occurrence in Natural Conditions

Both territorial species were present in relatively high abundance inside the supercolony in the absence of baits, but $F$. exsecta's presence was considerably more reduced at the control colonies (Fig. 1). Generally, more ant species occurred outside the polydomous system, and the submissive Myrmica spp. and F. cunicularia occurred in considerable numbers both inside and outside the supercolony (Fig. 1).

The abundance of $F$. pratensis was higher at the control nests (GLMM $z \geq 5.29, p<0.001)$, with no significant differences between them $(\mathrm{z}=2.09, N S)$, while considerable differences were recorded between the inside nests $(\mathrm{z}=5.29, p<0.001)$. The abundance of $F$. exsecta was higher inside the supercolony ( $\mathrm{z} \geq 8.82$, $\mathrm{p}<0.001$ ), and it also differed between both inside and outside nests $(\mathrm{z} \geq 3.2, \mathrm{p}<0.001)$. The abundance of $F$. cunicularia was also higher inside $(\mathrm{z} \geq 5.3, \mathrm{p}<$ $0.001)$, and significant differences were recorded among both inside and outside nests $(\mathrm{z} \geq 4.23, \mathrm{p}<0.001)$. In Myrmica spp. no consistent pattern could be revealed, there were considerable fluctuations in their abundance at the different nests. Thus significant differences were recorded in their abundance between the control nests, but also between the inside nests $(\mathrm{z} \geq 3.33, \mathrm{p}<0.004)$, while with the exception of O-1 and I- 2 nests ( $z=0.034$, $N S$ ), all other pairwise comparisons yielded significant differences in the favor of control nests $(\mathrm{z} \geq 3.35, \mathrm{p}<$ $0.004)$.

The average best GLMM model regarding the distribution of territorial species retained each of the original variables, with the exception of the model on $F$. exsecta's distribution at the control nests, which retained only the distance from these nests (Table S1). Inside the supercolony, the abundance of $F$. pratensis decreased with distance from the focal nests $(\mathrm{z}=-4.56, \mathrm{p}<0.001)$, whereas the opposite was valid for $F$. exsecta $(\mathrm{z}=5.62, \mathrm{p}<0.001)$. There was no significant relationship between the abundance of the two species $(\mathrm{z}<-0.76, N S)$, however. In a similar manner, at the control nests, the activity of $F$ pratensis decreased with distance from their nests $(\mathrm{z}$ $=-4.84, \mathrm{~N}=1188, \mathrm{p}<0.001)$, but this time $F$. exsecta was not influenced by the distance $(\mathrm{z}=0.48, N S)$. No significant relationship was revealed between the two territorials in this case either $(\mathrm{z}=0.42, N S)$.
All variables were retained in the average best model concerning the distribution of submissive species in nudum (Table S2). Inside the supercolony, the abundance of $F$. cunicularia was not affected by any of the included variables $(\mathrm{z} \leq 1.16, N S)$. On the other hand, the abundance of Myrmica spp. was negatively affected by the abundance of $F$. exsecta $(\mathrm{z}=-2.16, \mathrm{p}<0.05)$. The other variables did not have any significant effect on the abundance of Myrmica spp. $(\mathrm{z}<0.28, N S)$ either. At the control nests, the abundance of $F$. cunicularia foragers was affected by the distance from the $F$. pratensis nests $(\mathrm{z}=1.94, \mathrm{p}=0.05)$ and the abundance of $F$. exsecta workers $(\mathrm{z}=2.69, \mathrm{p}<0.01)$. In Myrmica spp., the abundance of $F$. pratensis had a significantly negative effect on their abundance $(\mathrm{z}=-2.37, \mathrm{p}=0.01)$. The other variables did not have an effect on any of the subordinate species $(-1.88<\mathrm{z}<0.82, N S)$.

Under Experimental Conditions: Discovery and Exploitation of Baits

Outside the supercolony, $F$. exsecta was almost entirely absent at baits (with only two individuals present), while the abundance of $F$. pratensis was quite high compared to other ant species (Fig. 2). This species was the most successful in bait discovery and exploitation around these nests (Figs. 2 and 3 ) and its abundance decreased with distance (full model) from the colonies $(\mathrm{z}<-5.21$, $\mathrm{p}<0.001$; Table S3).

In the absence of $F$. pratensis, submissive species were able to exploit baits, but also encounter species from the genera Lasius and Tetramorium at some baits (Figs. 2 and 3). However, the exploitation pattern was not predictable in any of the species $(\mathrm{z}<0.95, N S$; Tables S3-4). The average best model for $F$. cunicularia contained all the variables of the full model except for the distance (Table S4), but neither of the included variables had a significant effect $(\mathrm{z}<$ $0.89, N S$ ). In the model concerning Myrmica spp., only the abundance of $F$. pratensis was included (Table S4) which had a negative influence on Myrmica spp. ( $\mathrm{z}=$ $3.92, \mathrm{p}<0.001)$.

As expected, within the supercolony $F$. exsecta was the most abundant at baits followed by $F$. pratensis (Fig. 2 ). The majority of baits were mostly discovered and dominated by $F$. exsecta. The exploitation pattern of baits was predictable based on the nudum observations only in $F$. exsecta (GLMM z $=2.05, \mathrm{~N}=1026, \mathrm{p}<$ $0.05)$, and not in the other species $(\mathrm{z}<0.87, N S$; 

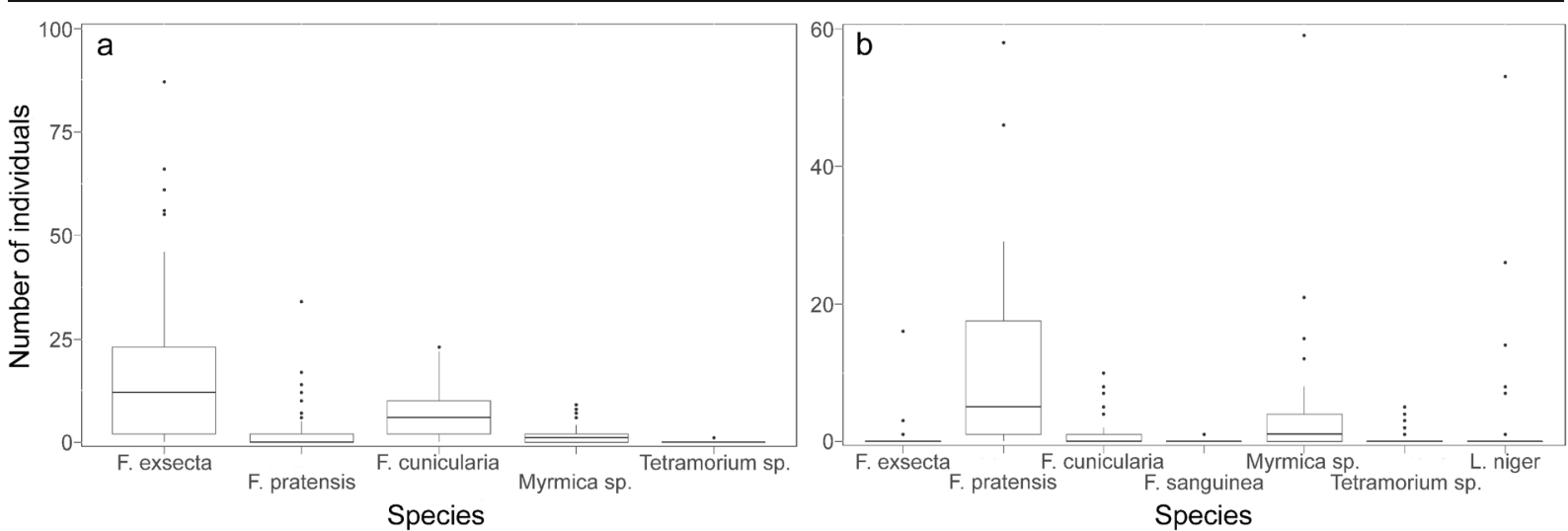

Fig. 1 Abundance of ant species in nudum around the nests inside (a) and outside (b) the supercolony (median, quartiles, min-max values, outliers)

Tables S3-4). Contrary to $F$. exsecta, $F$. pratensis never succeeded in monopolizing baits. In some cases, both territorials co-occurred with the submissive $F$. cunicularia. The full model was the best in both $F$. pratensis and $F$. exsecta (Table S3). The abundance of $F$. pratensis decreased significantly with distance from its nests $(\mathrm{z}=-5.82, \mathrm{p}<0.001)$, while that of $F$. exsecta increased $(\mathrm{z}=5.48, \mathrm{p}<0.001)$. The two territorials had a significant negative influence on each other's abundance $(\mathrm{z}<-2.84, \mathrm{p}<0.01)$.

Subordinate species were relatively more successful in discovering the baits than $F$. pratensis (Fig. 3). The best averaged models retained all variables (Table S4). The abundance of $F$. cunicularia workers was not influenced by the distance from the nests $(\mathrm{z}=1.5, N S)$, but it was negatively affected by the abundance of both territorial species $(\mathrm{z} \leq-5.46, \mathrm{p}<0.001)$, and by that of Myrmica spp. $(\mathrm{z}=-5.69, \mathrm{p}<0.001)$. Whereas, Myrmica spp. was negatively influenced by the distance $(\mathrm{z}=-2.53, \mathrm{p}=0.01)$, abundance of both territorials $(\mathrm{z} \leq-5.32, \mathrm{p}<0.001)$ and also abundance of $F$. cunicularia $(\mathrm{z}=-3.61, \mathrm{p}<0.001)$.

\section{Interactions Among Species}

During nudum observations, a single interspecific conflict was recorded in which one $F$. pratensis forager attacked and drove away a Myrmica spp. individual at nest O-2. However, at baits, several interspecific conflicts occurred (Table 1). Inside the supercolony, many aggressive interactions were recorded between the territorial and the submissive species (Table 1) but did not record any direct interactions between the two territorial rivals. Outside the supercolony, the two territorial species never occurred together, or with $F$. cunicularia. On the other hand, F. pratensis co-occurred with the submissive Myrmica spp. resulting in several aggressive interactions (Table 1). On the contrary, the facultative slave-maker $F$. sanguinea was not observed to co-occur at baits (neither at those situated close to its nests) with $F$. pratensis. Workers of the territorial species chased away both workers of those of the slave-maker and its F. fusca slave (Table 1).

\section{Discussion}

According to the competitive exclusion theory (Pisarski and Vepsäläinen 1989) the territories of territorial ant species cannot overlap. However, even within this theoretical framework, it is specified that the competitive strategy of a given species is context-dependent which is determined by the age and size of the colony (Savolainen and Vepsäläinen 1988; Zakharov 1991; Gallé 1994). Supercoloniality is the extreme territorial strategy where high nest density and intensive exchange of individuals among colonies (see Erös et al. 2009; Csata et al. 2012; Robinson 2014) could result in almost total exclusion of any species (see Czechowski et al. 2013). Since rival territorials are hardly ever found within a polydomous system, the general validity of this rule can be accepted. Under these circumstances, the peculiar natural setup discovered, where $F$. pratensis nests were found in the middle of a $F$. exsecta supercolony, offered the rare possibility to study the impact of the supercolonial species on the foraging strategy of $F$. pratensis. However, since there were only two $F$. pratensis colonies that could be studied, 
Fig. 2 Abundance of the four most abundant ant species at baits around the nests inside (white) and outside (grey) the supercolony (median, quartiles, min-max values, outliers)

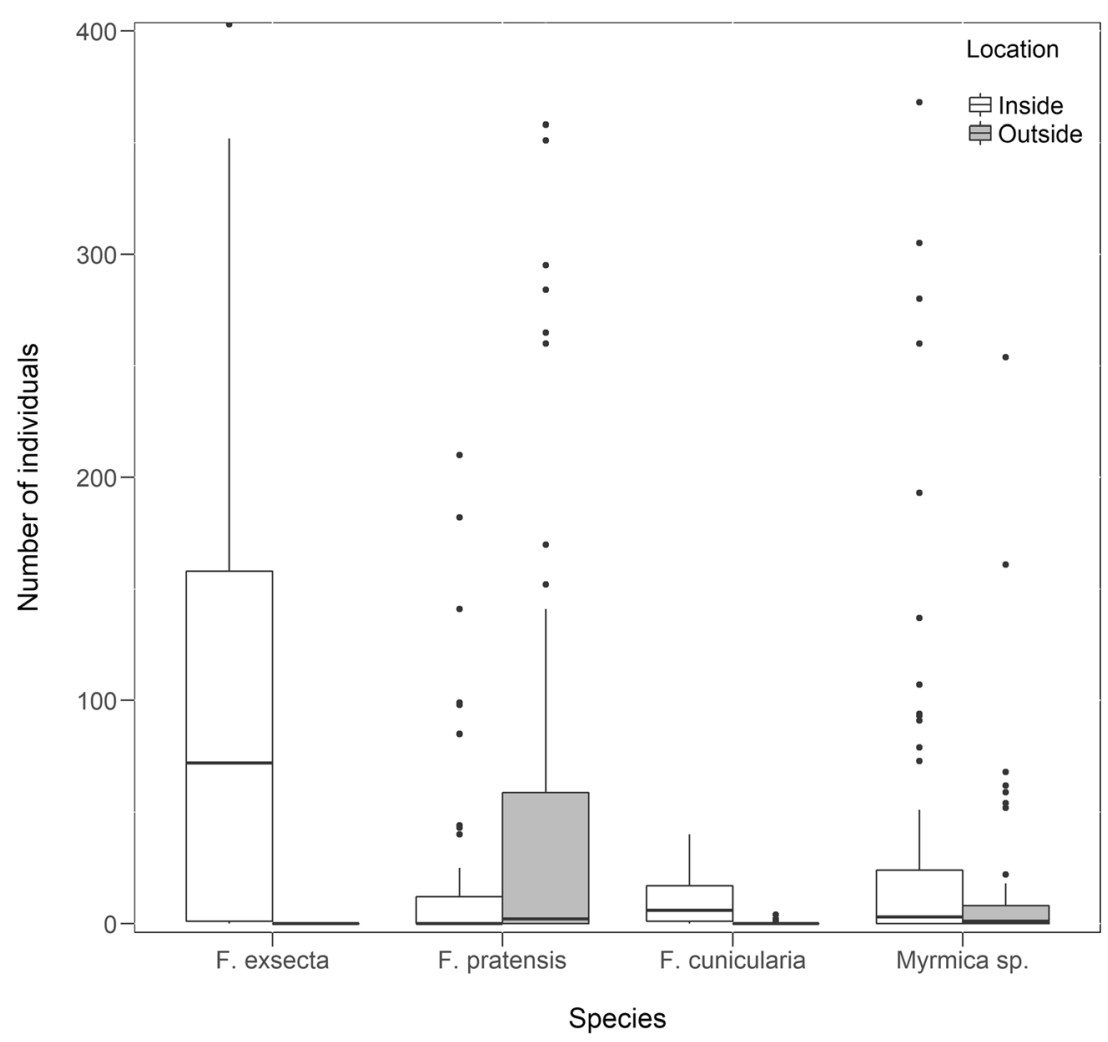

therefore the possibilities for generalization of the results should be handled cautiously.

As it was expected from an ant species living within a supercolony of another species, within the supercolony $F$. pratensis was present in quite low numbers around their colonies. A few meters farther from its colonies, the abundance of $F$. pratensis dropped sharply, while that of $F$. exsecta increased. The boundary between their territories was quite fuzzy without obvious 'no ant's land' as known from other observations on territorials neighboring each other (see Hölldobler 1979).

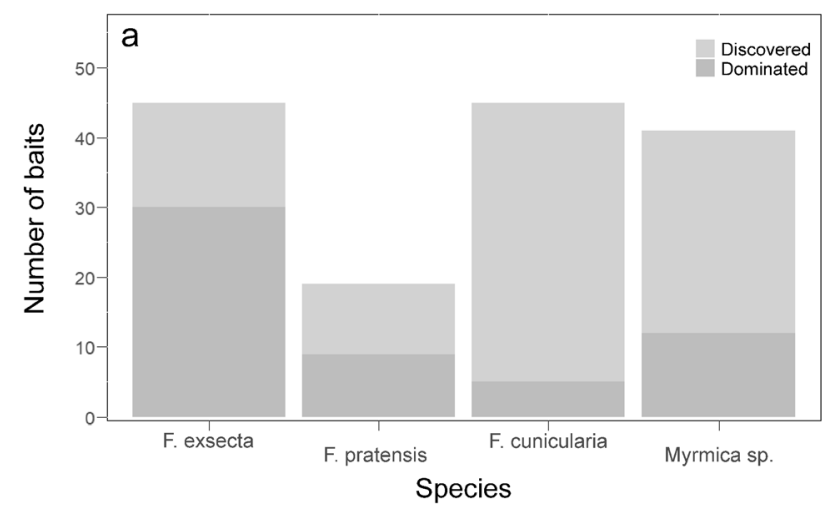

Other lower-ranked species found on the territory of the supercolony, like Myrmica spp. and F. cunicularia, are known to have adapted to living with territorial species. Thus, Serviformica species are fast in discovering new resources, and select smaller pieces of food in order to escape easier when harassed by the dominants (Reznikova 1981; Savolainen 1991). Myrmica species shift their activity period in a different time in order to avoid territorial Formica species foraging (Savolainen and Vepsäläinen 1989). Such adaptations make possible the long-term coexistence of submissives with the

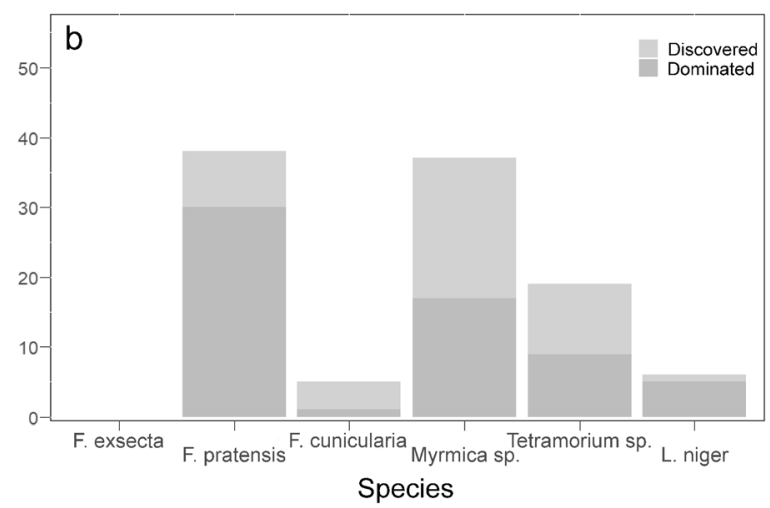

Fig. 3 Number of dominated and discovered baits by different ant species inside (max. 57 baits; a) and outside the supercolony (max 66; b) 
Table 1 Conflicts recorded at baits around the studied $F$. pratensis nests, and their outcome

\begin{tabular}{llll}
\hline Nest & \multicolumn{2}{l}{ Species and outcome of conflicts } & \multirow{2}{*}{ No. of conflicts } \\
\cline { 2 - 3 } & Won & Lost & \\
\hline I-1 & F. pratensis & Myrmica spp. & 3 \\
& & F. cunicularia & 1 \\
& F. exsecta & F. cunicularia & 9 \\
& & Myrmica spp. & 7 \\
& Myrmica spp. & F. pratensis & 3 \\
& & F. cunicularia & 3 \\
I-2 & F. pratensis & Myrmica spp. & 11 \\
& & F. cunicularia & 5 \\
& F. exsecta & F. cunicularia & 6 \\
& & Myrmica spp. & 6 \\
& Myrmica spp. & F. cunicularia & 1 \\
& & Myrmica spp. & 2 \\
O-1 & Fratensis & F. sanguinea & 3 \\
& & &
\end{tabular}

dominant species even inside a polydomous system (see Cerdá et al. 2013). Such changes could have been applied by $F$. pratensis as well. However, these strategies could also result in a lower amount of food intake that, could seriously limit or slow down the growth of colonies especially in larger-bodied species like $F$. pratensis.

While $F$. pratensis inside the supercolony was poorly performing, the control $F$. pratensis colonies outside the supercolony performed well and could be characterized by standard features of territorial species such as having high worker density around their colonies, a large number of aphid colonies tended that are crucial for the sustainability of strong colonies in territorial Formica ants, and competitive exclusion of lower-ranked species (Sorvari and Hakkarainen 2004). Moreover, tended aphid colonies were quite far from the nests thus contouring the borders of large territories in both control colonies (see Fig. S2-3). The presence of other ant species inside the $F$. pratensis territory was limited to those parts where $F$. pratensis was mainly absent, and their exploitation success was quite low which is consistent with the results of several other studies (Savolainen and Vepsäläinen 1988, 1989; Markó and Czechowski 2004, 2012; Czechowski and Markó 2005; Ellis and Robinson 2014; Adams 2016). Inside the supercolony, however, $F$. pratensis behaved quite differently which is similar to submissive species.
What remains unclear is the extent of plasticity in territorial ant species. That is whether such 'unexpected' coexistence could persist for a longer period. We visited the hereby studied $F$. pratensis colonies in the following years in order to confirm or dismiss the long-term coexistence hypothesis. While the control nests were healthy and thriving, signaling that for $F$. pratensis as such the general habitat conditions were still fair, those located inside the supercolony went extinct. Therefore, the loss of the nests located inside the supercolony would be consistent with the competitive exclusion theory, although we cannot rule out other mechanisms due to the small sample size.

The results of our study suggest that the strategies applied even by a territorial species could be contextdependent. They may be shaped by many other factors like the presence of other territorials, stronger competitors, and/or the abundance of available resources (e.g. Savolainen and Vepsäläinen 1988; Cerdá et al. 2013; Adams 2016; Johansson and Gibb 2016; Ślipiński et al. 2018; Stuble et al. 2017), and also most probably by nest size, making it possible for them to survive within a polydomous system at least for a while. The final disappearance of the studied colonies is consistent with the competitive exclusion, but also adds important nuances: colony foundation and development to a certain size is possible even for territorials within rival supercolonies.

Acknowledgements This work was supported by a mobility project of the Romanian Ministry of Research and Innovation, CNCS-UEFISCDI, project number PN-III-P1-1.1-MCT-20180038, within PNCDI III. We are grateful for the help of Enikő Csata, Enikő Német and Csilla Gál during fieldwork. The suggestions of László Gallé and Wojciech Czechowski greatly improved the quality of the manuscript. Róbert Gallé and Attila Torma kindly offered their help during data analysis. During fieldwork, we enjoyed the hospitality of the Apáthy István Field Station run by the Apáthy István Association. B.M.'s work was supported by the Bolyai János Scholarship of the Hungarian Academy of Sciences during manuscript preparation.

\section{Compliance with Ethical Standards}

Competing Interest The authors declare that they have no competing interests. The datasets generated during and/or analyzed during the current study are available from the corresponding author on reasonable request.

Open Access This article is licensed under a Creative Commons Attribution 4.0 International License, which permits use, sharing, adaptation, distribution and reproduction in any medium or format, 
as long as you give appropriate credit to the original author(s) and the source, provide a link to the Creative Commons licence, and indicate if changes were made. The images or other third party material in this article are included in the article's Creative Commons licence, unless indicated otherwise in a credit line to the material. If material is not included in the article's Creative Commons licence and your intended use is not permitted by statutory regulation or exceeds the permitted use, you will need to obtain permission directly from the copyright holder. To view a copy of this licence, visit http://creativecommons.org/licenses/by/4.0/.

\section{References}

Adams ES (2016) Territoriality in ants (Hymenoptera: Formicidae): a review. Myrmecol News 23:101-118

Bartoń K (2013) MuMIn: Multi-model inference. R package version 1.9.13. http://CRAN.R-project.org/package=MuMIn, published online 29 October 2013

Bates D, Maechler M, Bolker B, Walker S (2013) lme4: Linear mixed-effects models using Eigen and S4. R package version 1.0-5. http://CRAN.R-project.org/package=lme4, published online 25 October 2013

Braschler B, Baur B (2003) Effects of experimental small-scale grassland fragmentation on spatial distribution, density, and persistence of ant nests. Ecol Entomol 28:651-658

Cerdá X, Arnan X, Retana J (2013) Is competition a significant hallmark of ant (Hymenoptera: Formicidae) ecology? Myrmecol News 18:131-147

Csata E, Markó B, Erős K, Gál CS, Szász-Len AM, Czekes Z (2012) Information exchange centers in Formica exsecta Nyl. (Hymenoptera: Formicidae): outstations in a polydomous system. Pol J Ecol 60:177-186

Czechowski W, Markó B (2005) Competition between Formica cinerea Mayr (Hymenoptera: Formicidae) and co-occurring ant species, with special reference to Formica rufa L.: direct and indirect interferences. Pol J Ecol 53:467-487

Czechowski W, Radchenko A, Czechowska W, Vepsäläinen K (2012) The ants of Poland (with reference to the myrmecofauna of Europe). Warszawa, Warszawska Drukarnia Naukowa, PAN, Warszawa

Czechowski W, Markó B, Radchenko A, Ślipiński P (2013) Longterm partitioning of space between two territorial species of ants (Hymenoptera: Formicidae) and their effect on subordinate species. Eur J Entomol 110:327-337

Davidson DW (1977) Foraging ecology and community organization in desert seed-eating ants. Ecology 58:724-737

Debout G, Schatz B, Elias M, McKey D (2007) Polydomy in ants: what we know, what we think we know, and what remains to be done. Biol J Linn Soc 90:319-348

Ellis S, Robinson EJH (2014) Polydomy in red wood ants. Insect Soc 61:111-122

Erős K, Markó B, Gál C, Zs C, Csata E (2009) Sharing versus monopolizing: distribution of aphid sources among nests within a Formica exsecta Nyl. (Hymenoptera: Formicidae) supercolony. Isr J Entomol 39:105-127
Gallé L (1994) Formicoidea közösségek szerveződése. József Attila Tudományegyetem. ÖkológiaiTanszék, Szeged, pp $1-126$

Glen AS, Dickman CR (2008) Niche overlap between marsupial and eutherian carnivores: does competition threaten the endangered spotted-tailed quoll? J Appl Ecol 45:700-707

Gordon DM (2010) Ant encounters: interaction networks and colony behavior. Princeton University Press, USA

Goropashnaya AV, Fedorov VB, Seifert B, Pamilo P (2007) Phylogeography and population structure in the ant Formica exsecta (Hymenoptera, Formicidae) across Eurasia as reflected by mitochondrial DNA variation and microsatellites. Ann Zool Fenn 44:462-474

Grueber CE, Nakagawa S, Laws RJ, Jamieson IG (2011) Multimodel inference in ecology and evolution: challenges and solutions. J Evol Biol 24:699-711

Hölldobler B (1979) Territoriality in ants. P Am Philos Soc 123: 211-218

Hölldobler B, Wilson EO (1990) The ants. The Belknap Press of Harvard University Press, Cambridge

Johansson TH, Gibb H (2016) Interspecific competition and coexistence between wood ants. In: Stockan JA, Robinson EJH (eds) Wood ant ecology and conservation. Cambridge University Press, Cambridge

Levings SC, Traniello JA (1981) Territoriality, nest dispersion and community structure in ants. Psyche 88:265-321

Markó B, Czechowski W (2004) Lasius psammophilus Seifert and Formica cinerea Mayr (Hymenoptera: Formicidae) on sand dunes: conflict and coexistence. Ann Zool 54:365-378

Markó B, Czechowski W (2012) Space use, foraging success and competitive relationships in Formica cinerea (Hymenoptera, Formicidae) on sand dunes in southern Finland. Ethol Ecol Evol 24:149-164

Markó B, Czekes Z, Erős K, Csata E, Szász-Len AM (2012) The largest known polydomous system of mound building Formica ants (Hymenoptera: Formicidae) in Europe. NorthWest J Zool 8:287-291

Markó B, Czechowski W, Radchenko A (2013) Combining competition with predation: drastic effect of Lasius fuliginosus (Latr.) on subordinate ant species at the northern limit of its distribution. Ann Zool 63:107-111

Martin SJ, Helanterä H, Kiss K, Lee YR, Drijfhout FP (2009) Polygyny reduces rather than increases nestmate discrimination cue diversity in Formica exsecta ants. Insect Soc 56: $375-383$

Petráková L, Schlaghamerský J (2011) Interactions between Liometopum microcephalum (Formicidae) and other dominant ant species of sympatric occurrence. Comm Ecol 12:917

Pianka ER (1974) Niche overlap and diffuse competition. PNAS 71:2141-2145

Pisarski B (1982) Territoires et territorialisme de Formica (Coptoformica) exsecta Nyl. In: Pisarski B (ed) Structure et organisation des sociétés de fourmis de l'espèce Formica (Coptoformica) exsecta Nyl. (Hymenoptera, Formicidae). Mem Zoologi 38:163-203

Pisarski B, Vepsäläinen K (1989) Competition hierarchies in ant communities (Hymenoptera, Formicidae). Ann Zool 42:321329 
R Core Team (2018) R: a language and environment for statistical computing. Vienna, Austria: R Foundation for Statistical Computing. Retrieved from http://www.R-project.org/

Reznikova ZI (1981) Interspecific communication between ants. Behaviour 80:84-95

Robinson EJH (2014) Polydomy: the organisation and adaptive function of complex nest systems in ants. Curr Opin Insect Sci 5:37-43

Russell VL (2016) Least-squares means: the R package lsmeans. J Stat Softw 69:1-33

Sanders NJ, Gordon DM (2003) Resource-dependent interactions and the organization of desert ant communities. Ecology 84 : 1024-1031

Savolainen R, Vepsäläinen K (1988) A competition hierarchy among boreal ants: impact on resource partitioning and community structure. Oikos 51:135-155

Savolainen R, Vepsäläinen K (1989) Niche differentiation of ant species within territories of the wood ant Formica polyctena. Oikos 56:3-16

Savolainen R (1990) Colony success of the submissive ant Formica fusca within territories of the dominant Formica polyctena. Ecol Entomol 15:79-85

Savolainen R (1991) Interference by wood ant influences size selection and retrieval rate of prey by Formica fusca. Behav Ecol Sociobiol 28:1-7

Schultner E, Saramäki J, Helanterä H (2016) Genetic structure of native ant supercolonies varies in space and time. Mol Ecol 24:6196-6213

Seifert B (2000) A taxonomic revision of the ant subgenus Coptoformica Mueller, 1923 (Hymenoptera, Formicidae). Zoosystema 22:517-568

Seifert B (2007) Die Ameisen Mittel- und Nordeuropas. LutraVerlags-und Vertriebsgesellschaft, Görlitz, p 308
Ślipiński P, Markó B, Rzeszowski K, Babik H, Czechowski W (2014) Lasius fuliginosus shapes local ant assemblages. North-West J Zool 10:404-412

Ślipiński P, Markó B, Włodarczyk T, Czechowski W (2018) The foraging strategy of Formica sanguinea (Hymenoptera: Formicidae), a facultative slave-maker. Myrmecol News 26: $55-64$

Sorvari J, Hakkarainen H (2004) Habitat-related aggressive behaviour between neighbouring colonies of the polydomous wood ant Formica aquilonia. Anim Behav 67:151-153

Sorvari J (2009) Foraging distances and potentiality in forest pest insect control: an example with two candidate ants. Myrmecol News 12:211-215

Stuble KL, Jurić I, Cerdá X, Sanders NJ (2017) Dominance hierarchies are a dominant paradigm in ant ecology (Hymenoptera: Formicidae), but should they be? And what is a dominance hierarchy anyways? Myrmecol News 24:7181

Trigos-Peral G, Markó B, Babik H, Tăuşan I, Maák I, Pálfi Z, Ślipiński P, Czekes ZS, Czechowski W (2016) Differential impact of two dominant Formica ant species (Hymenoptera, Formicidae) on subordinates in temperate Europe. J Hym Res 50:97-116

Vepsäläinen K, Pisarski B (1982) Assembly of island ant communities. Ann Zool Fenn 19:327-335

Wiezik M, Gallay I, Wieziková A, Čiliak M, Dovciak M (2017) Spatial structure of traditional land organization allows longterm persistence of large Formica exsecta supercolony in actively managed agricultural landscape. J Insect Conserv 21:257-266

Zakharov AA (1991) Organizatsiya soobshchestv u murav'ev (Organization of Ant Communities). Nauka, Moscow 